
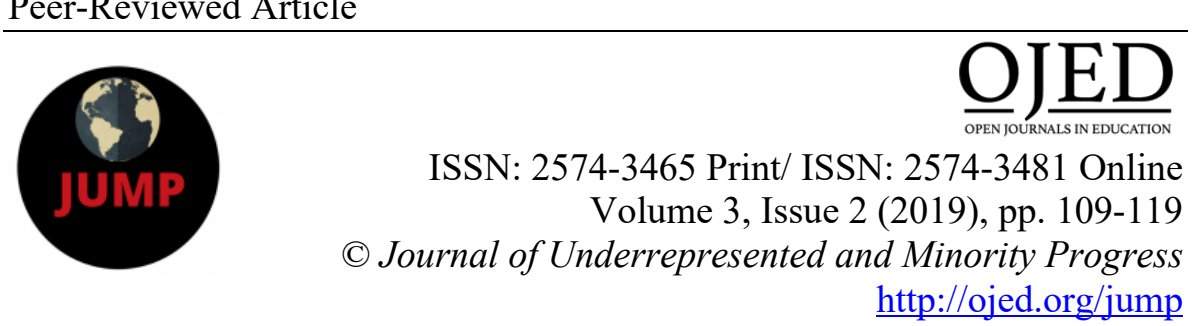

\title{
Critical Pedagogy and its Implication in the Classroom
}

\author{
Muhammad Sharif Uddin \\ Morgan State University, USA
}

\begin{abstract}
One of the most significant goals of teaching is to promote the critical thinking capability of students and thus, to create good citizens for a just society. Classroom teaching must also awaken the values of justice and equality in student minds. Critical pedagogy is a vital teaching strategy, one designed to strengthen the awareness of learners about justice and social equality, while improving their knowledge. Teachers today are busy in the classroom; they prepare the student for high stakes testing and, in the process, work to save the school from closing. As a result, teaching is most often testoriented rather than knowledge-centered. This paper aims to provide a few examples of how several teachers use critical strategies in the classroom and how these teaching methods affect student thinking and learning positively. Lastly, the paper argues that classroom teachers should employ critical pedagogy in the classroom to prepare students to gain critical thinking skills and to help create a just society.
\end{abstract}

Keywords: banking model of education, critical pedagogy, classroom teaching.

\section{INTRODUCTION}

Creating knowledge and enhancing student critical thinking capability are central to contemporary notions of schooling. In the $21 \mathrm{st}$ century, school authorities tend to measure teacher effectiveness and student achievement via various high-stakes tests. As a result, many teachers are not 
interested in engaging students meaningfully in learning; instead, they are busy preparing students for these tests, which will also enable to school to avoid closing. Frequently, teachers look for strategies to employ in the classroom to help students earn a good score, not simply to enhance their critical thinking capabilities, norms, values, or to bring about overall positive behavioral change. However, preparations for these high-stakes tests are neither helping many students in achieving good scores nor are they improving the critical awareness of students.

Preparing for high stakes testing is similar to Freire's (2016) Banking Concept of Education, which is a teacher-centered education, and memorizing is the primary strategy. Freire and many other scholars (e.g., Dewey, Gramsci) wanted to change the trend of transferring knowledge and argued for creating knowledge through various learner-centered activities like dialogue and problem-posing. Freire defined these learner-centered strategies as "Critical Pedagogy." In this paper, I look into Freire's critical pedagogy through a critical literature review from scholarly journal articles and books. First, the paper shows the history of the critical pedagogy movement; second, it explains what critical pedagogy is; third, it unveils wrong notions about the politicization of critical pedagogy; and finally, the paper presents some examples on different Freire's strategies that have been employed by the teachers in the classroom.

\section{HISTORY OF CRITICAL PEDAGOGY}

In the middle of the 20th century, the critical thinking movement in education started in Europe while Fascism and Stalinism were dominating the continent. The governmental domination over the economy, the lack of social equality, the presence of social and cultural hegemony, the importance of labor movements, and the plethora of governmental power exercised dictatorially were main spurs to the developments of the critical thinking movement in education.

Critical thinking originated in the Frankfort School and related to scholarly concerns about ideology and principles of education. According to Mahmoudi, Khoshnood, and Babael (2014), Habermas, Horkheimer, Adorno, and Gramsci were the pioneers of Critical Theory movements.

The focus of the Critical Theory is to understand the oppression of the individual, group, and society. These oppressions might be self-imposed or created via external forces. The critical theorists wanted to change the society by helping the oppressed to become emancipated; they engaged in a critique of a wide range of personal, social, cultural forces. In 2017 Kaya and Kaya identified Apple, Darder, Giroux, Gramsci, Illich, Kincheloe, McLaren, and many other philosophers as the fundamental theorists of Critical Pedagogy. Critical Pedagogy developed from Critical Theory as thinkers 
sought to understand better the existence of social dominance and to give students a voice to challenge oppression. Critical knowledge is also helpful for the privileged group, which can use it to realize that they are violating the rights of others.

Paulo Freire gave the critical thinking movement a new birth and he brought critical pedagogy into the mainstream of education. He became an iconic figure in contemporary education due to his critical pedagogy movement. His bitter experiences in his homeland, Brazil, inspired him to seek a way out, to break the silence of students. He noticed that students were passive learners in the classroom. They had no voice and no choice. They memorized what their teacher transferred to them. It was teacher-centered education, and Freire defined it as the "Banking Concept of Education," a system in which teachers just deposited their knowledge in the heads of students (Freire, 2016, p.73).

There was no creation of knowledge, and there was no intellectual and social development of the students. Freire realized that the social hegemony, oppression, and inequality would be continuing if the oppressed did not get their voice. He also realized that ignorance, illiteracy, and a culture of silence were the outcome of the economic condition of the oppressed, even though these people did not realize that they were deprived of their rights (Mahmoudi et al., 2014). To give the oppressed a voice and understanding, Freire established a gradual cultural revolution, one designed to liberate people from oppression, domination, and ignorance. He then introduced critical pedagogy in the education system.

\section{WHAT CRITICAL PEDAGOGY IS}

Critical Pedagogy is an effective strategy to enhance the critical thinking capability of students and to generate positive behavioral change in students' lives. This is a strategy that enhances student consciousness, understanding, and judgment. It gives students a voice to speak in the classroom. Freire (2001) defined critical pedagogy as a critical approach to education, highlighting the importance of having learners engage actively in their learning process, and being able to find and develop their own opinion and position.

Kaya and Kaya (2017) explain that critical pedagogy is a concept that addressed the problem of education and the education system itself. The purpose of critical pedagogy is to signal how questions of audience voices, power, and evaluation can actively work to construct schools into an environment where teachers and students can question the relationship between theory and practice, critical analysis and common sense, learning and social change (p. 182). 
Freire (2001) identified critical pedagogy as "a correct way of thinking that goes beyond the ingenious." It must be produced by the learners in communion with the teacher responsible for their education, he wrote ( $\mathrm{p}$. 43). Freire argued for learner-centered education, calling for a dialogue between teacher and student and he argued for problem-posing education. The dialogue-based approach is to engage students in questioning and exchanging ideas, to inquire and to learn. Problem-posing education is designed to engage the student in solving any problem through brainstorming. John Dewey also argued for child-centered education for creating the child as a good citizen. So, the main point of critical pedagogy is to engage students in learning and to make them active learners.

\section{WHY CRITICAL PEDAGOGY IS IMPORTANT}

Breunig (2005) says that the intended aim of critical pedagogy in education is to create a just society. Freire's ideology behind critical pedagogy was to liberate people from social and cultural hegemony, not to capture political power. Freire motivated illiterate peasants to break their silenced culture. He also urged the employment of a wide variety of different interactive teaching strategies (e.g., dialogical, problem-posing) in the classroom to enhance students' critical awareness. However, many scholars have spread a political banner over Freire's critical pedagogy theory. They point out that critical pedagogy arises from Marxism. For this reason, Freire was in exile for eight years from his homeland, Brazil, and he was not allowed to enter the United States.

Kaya and Kaya (2017) explain that Freire advocated education for the liberation for the poor and the oppressed through critical pedagogy. Mahmoudi et al. (2014) say that schools should be considered as places for social change and evolution. Schools should not only foster critical thinking among students, but they should also teach how to change the surrounding environments. Freire's notion was to wake the oppressed people, to help them to understand that they were oppressed. On the other hand, Freire also wished that the oppressors would realize that they were oppressing the underprivileged. Freire wanted a society where every person had equal rights and opportunities. Thus, he advocated for an education which would empower the oppressed and would give an understanding of social justice to the oppressors.

\section{IMPLICATION OF CRITICAL PEDAGOGY}

Many teachers think that it is not easy to employ different strategies in the classroom when there is only time for helping students to earn good grades on their report cards. However, during regular classroom activities, 
teachers can engage students in various activities through proper planning. Some of these activities are explained below.

\section{Dialogical Method}

Dialogue is necessary for education to create interaction between teachers and students and between students and other students. Freire (2016) asserted, "Only dialogue, which requires critical thinking, is also capable of generating critical thinking. Without dialogue, there is no communication, and without communication, there can be no true education" (p. 92). Dialogue places the interlocutors in close connection and helps to find out the facts. According to Freire (2016), dialogue needs some pre-requirements in the classroom.

First of all, the teacher and student should have a love for each other. When there is love, there is a commitment. The teacher must have a positive mentality and show this to the students; that will indicate that the teacher wants to engage the student in learning. Secondly, the teacher should not think of himself or herself as above the students. Teacher and student must consider themselves as equal partners in dialogue. Finally, the teacher should have faith in the students that they are not empty vessels; instead, they have some knowledge. Through using this knowledge, the student can engage himself or herself in dialogue and can achieve more knowledge.

Dialogue gives voice to the student, and it is a technique to break the silent nature of the students and the monologue of the teacher. According to Freire (2016) through love, humanity, and faith both teacher and student come to a horizontal relationship and build a mutual trust which helps to bring a logical consequence (p. 91). Lyle (2008) defines the dialogic approach as a vehicle for increasing pupil engagement at a deep level and raising the quality of classroom interaction.

Dialogical approaches that Freire suggested is the most effective method in teaching for enhancing student's critical thinking capability. It creates a two-way communication where the student and teacher take an active part. Shih (2018) says that Freire advocates that teachers and students should have an equal dialogue instead of teachers holding absolute authority. When there is love, humanity, and faith among the interlocutors, good cooperation is formed, which enables the interlocutors to engage in critical analysis. Freire's dialogical approach is not a new technique in teaching. In ancient Athens, Socrates used to teach people through dialogue. 
In 400 B.C., Socrates used to teach people through the method of dialogue. In Meno (Plato, trans. 1981), Meno and Socrates had a conversation on virtue. Meno gave four definitions of virtue but could not establish any of his definitions while answering Socrates's questions. Socrates did not say that Meno's definition was wrong; instead, with the dialogical approach, Socrates created a situation in which Meno himself could understand that he did not give the correct definition of virtue. Socrates's intention was not to prove Meno's lack of knowledge. Rather, Socrates's intention was to inspire Meno to be his own critic, to judge the authentication of his answer and to come to an acceptable solution.

The Socratic method is still the most robust teaching strategy in enhancing critical thinking. In this method, the teacher asks a question to the students but does not provide an answer. The teacher helps the students to find out the accurate answer through critical thinking and inquiry. Dialogical approaches that Freire suggested offer an effective strategy of teaching for enhancing student's critical thinking capability.

\section{Connecting Learning with Real Life Situations}

Freire's banking concept of education shows how learning is far from a real-life situation. Students only memorize what is transferred by the teacher. This memorization does not bring any tangible learning outcome in the life of a student. Dewey (1902) expressed his observation of how far the curriculum and education are from a child's world. There is no connection between a child's learning and his real-life situation. This kind of learning has a minimal effect on improving students' critical thinking. There is no selfrealization and no critical awareness in education which cannot connect the real-life situation. Dewey (1902) said, "There is some gap in kind (as distinct from a degree) between the child's experience and the various form of subject matter that makes up the course of study" (p. 11).

Duhaylongsod, Snow, Sellan, and Donovan (2015) have given an example of a history lesson on critical thinking enhancement. The authors have designed instruction for grade six on the Egyptian civilization, and they implement it in the classroom of a middle school. In their instructional strategy, they add a debate activity on "Egyptian Pharaohs: Wise investors or wasteful spenders?" The class was divided into two groups and the students debate on that topic.

The authors and teachers were very pleased when they observed the outcomes of the debate. The students defined the situation as a historical 
phenomenon. They used objects, statements, texts, and pictures to explain, compare, and evaluate the arguments. Then the students argued in a real-life situation. Duhaylongsod et.al (2015) wrote that

The reader's theater launch for the unit on the choices of pharaohs made between irrigation and pyramid construction is a fictional conversation among modern day middle school students who disagree about whether their school is being wise or wasteful by building a new swimming pool. The characters of the "wasteful spending" side emphasize the unfairness of the decision, claiming that only a few students will benefit from the pool while the majority will continue to suffer from the school's decrepit bathrooms and a paucity of computers. The characters in the "wise investment" camp stress just how great a pool would be for school sports and the entire community, as it would put their school "on the map." Each side's arguments have correlates in the debate about pharaohs as wise investors or wasteful spenders. (p. 398)

\section{Engaging Students with Out-of-Book Activities}

The critical awareness improvement of the students depends on the teacher. The teacher can design lessons based on student capacity. The classroom teacher knows students well and can set up classroom strategy which can enhance students' critical awareness. A free and fair classroom environment and communication are essential for learning, creating a space where the students are not afraid to ask any question. This kind of environment helps the student to be an active learner while the banking concept of education makes the student a passive learner. Freire (2016) compared the banking concept's classroom to an ivory tower which has no connection with students.

Ms. Clifford and Ms. Friesen, two open-area classroom teachers of University Elementary School, Calgary, Canada, have shown their creativity to enhance six to seven years old students' critical thinking capability. Clifford and Friesen (1993) describe their students as follows:

Ten students were second-language learners. One child was in a wheel chair, several had behavioral problems severe enough that social workers, psychologists, and psychiatrists had been involved before the children entered grade one. Some had been identified as gifted, others as learning disabled. (p. 340) 
They had a storytelling time once a week. The authors gave an example of how a simple Rumpelstiltskin story engaged their students. These six and seven-year old students discussed some critical questions and debated actively after the story. The students raised questions about whether parents could put children in danger, whether or not people could ask for help without expecting anything in return, whether a parent could give their child away. The authors were amazed by the conversation of these six/seven- year old kids.

Clifford and Friesen (1993) have described another observation. One day they took their students outside the classroom and asked them to follow their shadows to try to make them fall in a different direction. Five of their students came to them and told them that they could make a clock that indicated the time. Four children stood up in a circle. One stood as twelve, one as three, the third one as six, the fourth one as nine, and the fifth one in the middle which indicating the sunlight. The students also discussed themselves about their observation that, if a person stands in the same place the whole day long, the shadow changes as the earth moves. Sundials will not work rainy day as clouds block the sunlight. Who can indicate time with a single hand? Why is one's shadow longer in the evening but shorter in the noon? No-one can make time go fast.

\section{Hands-on-Study Activities}

Paul (1994) engaged his third graders in hands-on activities to improve their critical awareness. The author and his students made "Sweet Cake Town" inside the classroom. They opened the Fidelity bank, toy store, Value Plus Clothing Store, Art gallery, and Sweet Cake Zoo and showed their performance in doing the job correctly. The students could apply for any job explaining their fitness for the job. Paul (1994) wrote:

In the last ten minutes of every day, each child evaluated his or her "job of being a good student" by filling out a pay sheet. On the top half of the pay sheet was a grid for the students to fill in, with one column for each day of the week and a row for each aspect of the "job of being a student": their school work, their behavior, and the government job. Based on their self-evaluation, students wrote how much they should be paid in accordance with the rules. On Friday afternoon, I paid the students and then they had chance to buy the use of activities. Before that they were required to pay rent for desk, and taxes for municipal salaries. (p. 313) 
The author's hands-on-study activities connected the community, and even the low scored student showed performance, and at the end, the academic year, all students got a sound report card.

\section{Problem-Solving Strategy}

Freire introduced the problem-posing strategy to replace the banking concept of education. Problem-posing education is being widely used in Singapore. The country is one of the leading countries for education. The problem-posing strategy helps students to be engaged in orderly thinking, looking for a better solution for any problem. Students first decide on a problem, then do the brainstorming and come to an initial solution. After that, students analyze the first answer and come to a final solution. Through the process, students achieve skills in higher order thinking, using Bloom's Taxonomy. Freire (2016) classified problem-posing education as a tool for transformation.

In problem-posing education, people develop their power to perceive critically the way they exist in the world in which they find themselves: they come to see the world not as a static reality but as a reality in process, in transformation. (p. 83)

I want to cite an example of a problem-posing activity from my own experience. One day, our philosophy professor raised a discussion in the class. He related that in a company which has a large number of shareholders, many can cast their vote to decide who will run the administration of the company. The person who does not have stock cannot cast a vote. So, in a state where many homeless people have no land or property, they have no right to vote. Then the professor asked us whether we support his arguments or not, and also asked to defend our answer with proper logic. The professor raised this question to enhance our critical analysis skills.

\section{CONCLUSION}

Kincheloe (1993) says that teachers and parents focus on children's education in such a manner that it is away from the child's point of view and their construction of reality. To help students create knowledge with keen understanding, teachers need to employ critical pedagogy in the classroom. Moreover, critical pedagogy is not a new strategy in teaching and learning. Figures from Socrates to many of today's most prominent educators have been using different student-centered classroom approaches to help students by engaging them in learning and creating knowledge. 
Enhancing students' critical awareness is a goal of education, and teachers are the most crucial adults to guide students and can make them enthusiastic about learning for life. Freire's educational theories are for the critical consciousness of the students. Freire wanted education to remove the curtains between the privileged class and the deprived groups of the society. All students would get equal access and equal opportunity in education, and there would be no social differences among the students. Social and cultural hegemony would be no more in existence.

A classroom teacher who knows the students well should design a lesson plan that helps to engage students in learning activities using the dialogical method. The design should include the classroom strategy on how the students will be engaged in dialogue to find out the solution of the given problem. Student-student or student-teacher dialogue will make a clear and reasonable judgment of the issue. The teacher will play the role of facilitator to support, so that the students reach a valid conclusion. Teacher-guided dialogical approach will help the students to achieve a growth mindset of thinking with openness and reasoning.

Connecting the lesson with a real-life situation is also essential to enhance the ability of students to use a reason-seeking approach. In the era of high stakes testing, teachers keep the students busy in the classroom to get a sound report card. Thus, the students think that they study for achieving a better score and do not consider learning as their life-changing lessons. The teachers must keep in mind that learning is not out of life. Thus, the teacher's planning should include a strategy that can connect the content with a reallife situation. The previous discussion shows how the teachers have connected Egyptian civilization with the school's pool. This kind of situation helps students to critique the reasons constructively, using rational thinking.

The teacher should not consider that knowledge is hidden only in the content of the curriculum. The teacher can use many other resources like the story, drama, and students' cultural presentations. These kinds of resources are supportive for the students, enabling them to be creative and think consciously. Moreover, the teacher can create a classroom community where students can play a different role and have the chance to employ their knowledge to gather more knowledge.

\section{REFERENCES}

Breunig, M. (2005). Turning experiential education and critical pedagogy: Theory Into praxis. Journal of Experiential Education, 28(2), 106-122. 
Clifford, P., \& Freisen, A. L. (1993). A curious plan: Managing the twelfth, Harvard Educational Review, 63(3), 339-358.

Dewey, J. (1915). Democracy and Education: An Introduction to the Philosophy of Education. New York, Macmillian.

Duhaylongsod, L., Snow, C. E., Sellan, R. L., \& Donovan, M. S. (2015). Towards Disciplinary literacy: Dilemmas and challenges in designing history curriculum to support middle school students. Harvard Educational Review, 85(4), 587-608.

Freire, P. (2016). Pedagogy of the oppressed. New York; Bloomsbury

Freire, P. (2001). Pedagogy of freedom: ethics, democracy, and civic courage, Maryland; Rowman and Littlefield Publishers, Inc.

Kaya, C., \& Kaya, S. (2017). Perspective teachers' education belief and their views about the principles of critical pedagogy. Journal of Education and Learning, 6(4), 181-190.

Kincheloe, J. L. (1993). Towards a critical politics of teacher thinking mapping the postmodern. Connecticut, Westport; Bergin \& Garvey.

Lyle, S. (2008). Dialogic teaching: Discussing theoretical contexts and reviewing Evidence from classroom practices. Language and Education, 22(3), 22240.

Lather, P. (2005). Critical pedagogy and its complicities: A praxis of stuck place. Educational Theory, 48(4), 487-497.

Mahmoudi, A., Khoshnood, A., \& Babael, A. (2014). Paulo Freire's critical pedagogy and its implication in curriculum planning. Journal of Education and Practices, 5(14), 86-92.

Paul, S. S. (1994). Elementary school curricula and urban transformation. Harvard Educational Review, 64(3), 309-331.

Plato (1981). Menu (G. M. A. Grube, Trans). Indianapolis, Indiana; Hackett Publishing Company Inc. (Original work publish 390 B.C.)

Shih, Yi-H. (2018). Some critical thinking on Paulo Freire's critical pedagogy and Its critical implication. International Educational Studies, 11(9), 64-70.

Muhammad Sharif Uddin, is a scholar in Urban educational Leadership Program at Morgan State University, USA. He also works as a graduate research assistant and as an adjunct faculty in the Department of Teacher Education at Morgan. He is a Fellow of International Leaders in Education Programs. His research interest is teacher education, critical pedagogy, holistic education, and curriculum and instruction. His email address is uddinsm@gmail.com 